Japanese Yearbook on Business History - 1998 / 15

\title{
The Innovativeness and Adaptability of Department Stores in Japan
}

\author{
Birth, Growth, Maturity, and Crisis
}

\author{
Kazutoshi Maeda \\ Komazawa University
}

\begin{abstract}
INCE THE START of the 1990s Japanese department stores have been crying havoc over the crises endangering their very existence, both on the enterprise level and on the level of their type of retailing. ${ }^{1}$ Department stores' loss of market share in the retail sector already began with a process in which "general supermarkets" 2 achieved sudden growth in the 1960s and first half of the 1970s, and from the second half of the 1960s large-scale, specialty chain stores dealing in one particular type of merchandise such as electrical household appliances, or books and magazines, or pharmaceuticals, or clothing (including kimonos), or shoes rose to prominence, with

1 The following books are useful sources of information on department store trends in the 1990s. Hiroshi Ejiri, Hyakkaten no saikō [The revival of the department store] (Chūō Keizaisha, 1994) and Motoshige Itō, Hyakkaten no mirai [The future of department stores] (Nippon Keizai Shimbunsha, 1998).

${ }^{2}$ These are variously called "supermarkets," "supermarket chains," "mass merchandisers" or "mass retailers," or "GMS" (general merchandise stores), but in this study I will refer to them as "general supermarkets."
\end{abstract}


a consequent advance in diversity in the form of retail selling. In 1972 department stores' $8.5 \%$ share of total retail sales was passed by the share of general supermarkets ("self-service stores" in the statistics), which stood at $8.7 \%$, and after 1972 the share fell to the 7 percentile mark. ${ }^{3}$ In that same year the general supermarket Daiei outstripped Mitsukoshi Department Store as the top in sales in the retail industry. Thus 1972 was, from the aspect of department store retailing and on the enterprise level, a turning point in department store history.

The department store is a form of large-scale retail operation that deals with a diversity of goods (principally goods that customers shop around for, comparing prices and quality) and services and that organizes the display and sale of these goods according to different categories, or "departments." This form of retail operation appeared in the West from the second half of the nineteenth century through the early twentieth century, along with certain sales methods such as cash purchase and fixed-price sales, quality guarantees, and the possibility of returning defective items. In Japan moves to establish department stores began from 1904 with a few merchants in the large cities, principally traditional dry goods stores (meaning stores dealing in kimono fabrics), and by the middle of the 1920s authentic department stores modeled on those in other countries appeared in the large cities. Meanwhile, in the 1910s the wave of department stores reached as far as the cities in regional parts of the country.

In the period of growth, management of department stores retained many of its traditional elements; still, in the 1910s and 1920s changes came to be seen in such things as the class of customer targeted, the makeup of the merchandise on sale, and pricing policies, and steady advances were made in increasing the number of a company's stores and the size of individual stores. The 1920s are usually described as a period of chronic recession, but it also was a decade in which Japanese society and the Japanese market underwent great change. During this decade the department stores embarked on strategies that were aimed at mass popularization, and in doing this they made significant growth. In the late 1920s one new department store after another was established in the large cities and in region-

\footnotetext{
${ }^{3}$ Nippon Hyakkaten Kyōkai Chōsaka, comp., Nippon Hyakkaten Kyōkai tōkei nenpō 1985[Annual report of Japan Department Stores Association statistics] (Japan Department Stores Association, 1986), p. 87.
} 
al cities. The appearance of a train-terminal type of department store operated by electric railway companies, in particular, meant a type of department store came to the fore that was very different from the traditional department stores that grew out of earlier-existing retail merchants, particularly dry goods stores. Another new form of retail operator that appeared among the existing department stores was the variety story that had introduced a chain system.

The aggressive management of department stores in the second half of the 1920s led, on one hand, to intense competition between department stores and disparities between one enterprise and another, and, on the other hand, a campaign against department stores on the part of small and medium-sized retail merchants. Even into the 1930s the department store business as a whole expanded, even though there were some enterprises that would be cut back or eliminated. When the campaign against the department stores was growing in vehemence the department stores moved from a state of selfcontrol agreements to having their operations regulated by the Commercial Guild Ordinance of 1932 and later by the (first) Department Store Ordinance (in force from 1937). Even under legal regulation the department stores at first continued on their merry way, but after reaching a peak in 1939 they would feel the impact of wartime controls and their free business activities would come to an end. 4

Statistical data on department store enterprises, numbers of stores, sales totals, numbers of employees, and share of the retail industry market prior to the end of World War II are extremely fragmentary, and it is impossible to obtain a chronological grasp of the state of affairs in the industry, or of trends. By good luck we have the results of an extraordinary national survey taken in 1939, just when department store expansion reached its peak; according to this survey the number of stores classified as department stores (as defined by the Department Store Ordinance) ${ }^{5}$ was 203 (as of 1 August 1939),

${ }^{4}$ See figure 1 on p. 361 of Japan Department Stores Association, ed., Nihon Hyakkaten Kyökai jünen shi [The first ten years of the Japan Department Stores Association] (Japan Department Stores Association, 1959).

${ }^{5}$ The ordinance defined a department store as a retail business selling many different varieties of goods related to clothing, food, and household items and having, in the large cities, a floor space of at least 3,000 square meters and, elsewhere, a floor space of 
the number of employees was 64,990, and the total sales figures for the year (1 August 1938 to 31 July 1939) was $¥ 668,973,892$. The respective figures for retail shops as a whole (excluding production retail business, wholesale-retail business, and street peddling) were $1,198,416$ shops, $2,606,751$ employees, and $¥ 5,423,427,040$. So if department stores are compared with the general retail shops, it becomes clear that the former took in about $10 \%$ of the total amount of sales taken in by the former and the latter combined.

Let us now take a quick look at the fortunes of department stores after World War II. First of all, we do not know their exact number immediately after the end of the war. We do know that, in 1948, 72 companies were members of the Japan Department Stores Association (which was set up in 1948 under the Japanese name Nippon Depātomento Sutoa Kyōkai, then changed the name in 1956 to Nippon Hyakkaten Kyōkai), and that in 1950 there were 69 member companies, with 111 stores. ${ }^{6}$ Department store business activities were severely limited during this time by the distribution control of materials and GHQ's requisitioning of department store shops. Nevertheless, the easing of controls and the gradual release of requisitioned buildings, plus the brisk business generated by special procurements resulting from the outbreak of the Korean War in June 1950, triggered an expansion in department store activities. As a result, if we take 1938 as an index of 100 , we find that, though in 1950 real sales were only $62.4 \%$, in 1953 they were $108.3 \%$, and whereas floor space in use in 1950 was only $68.1 \%$, in 1954 it was $105.1 \%$-in other words, in both respects department stores had surpassed the prewar level.

Because the first Department Store Ordinance had been repealed in 1947, in the first half of the 1950s department store business activities were subject only to the restrictions of the Anti-Monopoly Law, and legal restraints no longer existed in regard to building new stores or expanding existing ones. As a result expansion strategies were in evidence, but the special features of this period were the growth of train-station department stores and the invasion of Tokyo by Kansai department stores. While on the one hand competition among the

at least 1,500 square meters.

${ }^{6}$ The data given in this paragraph can be found in Table 2 on: p. 366 of Ten-Year History of Japan Department Stores Association (cited in note 4 above). 
department stores grew in ferocity, on the other hand there also was greater friction between the department stores and the wholesalers and small and medium-sized retail merchants, with the result that in 1956 the second Department Store Ordinance was enacted. ${ }^{7}$

Department store sales soared from the mid-1950s to the early $1960 \mathrm{~s}$. The rate of increase exceeded the rate of increase in individual consumption expenditure, a situation that lasted for years: there were high rates of increase in 1956, 1957, 1960, and 1961. As a consequence the department stores' share of total retail sales increased, reaching $9.5 \%$ in 1962. But that year marked the peak of their sales; in the following years sales followed a downward curve, and their position within the retail commerce sector slowly fell. Increases in sales during this period were achieved with hardly any increase in floor space in use attendant upon new or expanded stores (except in 1956 and 1957, when companies finished construction of stores they had started building to get in under the wire before the 1956 Department Store Ordinance took effect). During this period of growth the inroads made by train-station department stores owned by electric-train companies were conspicuous, and department stores in the subcenters of metropolises (e.g., in Ikebukuro or Shinjuku in Tokyo) enjoyed good development. Regional department stores that had grown out of dry goods stores or general grocery stores also increased in numbers, with consequent increases in business floor space and sales; these increases became most notable in 1968 and later. I might mention here that the number of stores owned by department stores (as defined in the old and new Department Store Ordinance) stood at 125 in 1955 and 138 in 1956, and 166 in 1962.

From 1963 until 1973 (when the Large-Scale Retail Stores Law regulating all retail merchants located in large-scale retail stores was enacted to replace the Department Store Ordinance), the brakes were put on department store growth. One of the reasons was the development of such new forms of retail trade as general supermarkets and specialized chain stores. While their sales were consistently higher than the growth rate in the retail trade as a whole, their share of retail sales relatively declined. Department stores lagged behind their new

${ }^{7}$ According to ordinance, a department store was defined as a business dealing in the sale of goods (including processing and repairs), with a floor space of at least 1,500 square meters used for those purposes (in the six large cities, at least 3,000 square meters). 
forms of business rivals during this period in responding to a slowdown in the rate of growth in real individual consumption, to the lowprice orientation of consumers, to population shifts to the suburbs of cities, to the trend to income leveling, and similar phenomena. Besides this slowness to react to the external environment, the courses taken by department store managers, who had become conservative in their thinking, strengthened reliance on manufacturers and wholesalers and reinforced the impression that department stores were in the business of renting floor space. ${ }^{8}$

The growth rate in department store turnover, or sales, slowed down very rapidly from 1975 on (with one exception: from the end of the 1970 s to 1980 they raised their rate of climb-even though only by one digit-and recovered their profitability, to the extent that this was called "the rehabilitation of the department stores"). This proved to be only a temporary phenomenon, however; in 1982 and 1983 their sales showed a sharp drop, and in the first half of the 1980s they experienced such a period of severe recession that they were said to be "in the winter of their years" and "a structural recession industry." But then department store growth rebounded during the upward swing taken by the Japanese economy as a consequence of the Plaza Accord reached in the autumn of 1985 . This rebound reached its peak of $10.1 \%$ growth in 1989. Because the recovery in this period was not brought about by reforms in business structure but as the result of a simple response to bubble consumption, once the bubble burst the department stores tumbled into an unprecedented crisis lasting 44 months, from March 1992 to October 1995, in which sales figures continued to fall below those of the preceding year. While there were 378 stores in 1990, increasing to 416 in 1991 and 425 in 1995, department stores are now being driven into making another major change in their business approach.

Thus far by way of a general background. Now we can turn to look at the shifts in department store business management from before World War II up to approximately 1990, with a focus on innovativeness and adaptability.

${ }^{8}$ Eiichi Nishi, "Hyakkaten keiei ni miru 'amae no kōzō'” [The "structure of amae" seen in department store management], Shükan Töyō Keizai 4 November 1976, special issue on distribution, pp. 114-15. 


\section{INNOVATIVENESS AND CONSERVATIVENESS IN THE PROCESS OF EMERGENCE AND GROWTH}

Seen in terms of family trees, the principal types of department stores in Japan are those derived from traditional dry goods (meaning kimono fabrics) stores and those that are train-station department stores owned by electric railway companies. Another type derives from any of an assortment of traders; thus a department store in this category might go back to a regional products (chiiki no bussan) store, a farmmachinery importer, a food store, or the like. The years in which the predecessors of the department stores were founded are scattered widely; according to a survey of the Department of Commercial Administration, Commercial Affairs Bureau, the Ministry of Commerce and industry (published in January 1933), of the 89 department stores existing then, the 32 founded in the period 1928-32 made up the most numerous group, but of the rest, 19 stores traced their histories back prior to 1867,12 to the period $1868-97$, and 6 to $1898-1907 .{ }^{9}$ This shows that there were quite a few stores founded in Japan even before the year 1904, when the impetus to establish department stores began. As of 1933, also, there were 7 stores with a floor space of 10,001 tsubo or more ( 1 tsubo being equal to 3.3 square meters), and five of these seven had been founded before 1867.10 Though not all of these could be called dry goods stores in the strict sense at the time they were founded, they all went on to develop from a dry goods store into a department store.

Although such sales methods as cash purchase and fixed-price sales, elements so necessary in modern retail trade, had been adopted by dry goods businesses operation under the Tokugawa administrative system in force until 1867, many businesses faced ruin in the process of the move into modern society. Despite the problems, in the early second half of the 1880s the Shirokiya Dry Goods Store (hereafter, Shirokiya) and the Mitsukoshi Dry Goods Store (renamed Mitsui Dry Goods Store in 1893, then Mitsukoshi Dry Goods Store in 1904;

\footnotetext{
"This information is contained in "Zenkoku hyakkaten tōkei" [National statistics for department stores], Chōsa ihō [Survey bulletin], no. 1 (1933), published by the Japan Department Store Business Guild.

${ }^{10}$ Ibid.
} 
hereafter referred to simply as Mitsukoshi) broke out of their dry goods shells and began dealing in Western clothing as well, and some of their shops introduced the sale of items on display in the second half of the 1890s. At Mitsukoshi a whole series of management innovations were carried out when it was still known as Mitsui Dry Goods Store: reform of the shop assistant system; establishment of a departmental system corresponding to functions; the adoption of Western accounting methods; the appointment of new personnel and the employment of female shop assistants. These were all the work of Yoshio Takahashi, who had gone to the United States to study the operations of the Wanamaker Department Store, and who had accepted the business methods of that department store as his ideal."1

The reforms at Mitsui Dry Goods Store were not carried out thoroughly, and in 1904 the organization was separated from the direct control of Mitsui and reestablished as the Mitsukoshi Dry Goods Store Incorporated. The management policy of the store was announced as "to bring into being a small portion of what is done in department stores in the United States," but when Ösuke Hibi, who took over the management of the new company in its early years, returned from an inspection of department stores in the United States and Europe in 1906, the goal changed to the creation of a department store modeled on Harrods of London.

As early as 1905 the store was dealing in cosmetics, hats, and children's apparel; in 1906 it reopened its Western-clothing department; in 1907 it began dealing in, or expanded its operations in, bags, footwear, Western umbrellas, combs, chopsticks, shoes, cafeterias, and a photography department; in 1908 it began handling jewelry, tobacco products, and stationery, so it had a full range of goods of all sorts except for foodstuffs. In 1914, when the new wing of its main store (a Renaissance-style building with one floor underground and five floors aboveground, with a total floor space of 12,210 sq. meters, and equipped with five elevators and one escalator) opened, it also had sections for Western alcoholic beverages and for foodstuffs, as well as a section for gardening equipment; in other words, it had all the makings of a department store prototype as far as the makeup of the goods sold was concerned. ${ }^{12}$

11 Mitsukoshi Ltd., Kabushikigaisha Mitsukoshi 85nen no kiroku [A record of the first 85 years of Mitsukoshi Ltd.] (1990), pp. 32-37. 
What Mitsukoshi was doing became a great stimulus to other dry goods stores in the large cities. From around 1907 Shirokiya, Daimaru Dry Goods Store (hereafter, Daimaru), Takashimaya \& Co., Itō Dry Goods Store (renamed Matsuzakaya in 1925), Matsuya Dry Goods Store (renamed Matsuya Tsuruya Dry Goods Store in 1919, then Matsuya Dry Goods Store in 1924; hereafter, Matsuya), and other stores moved to break out of their shells and take on the department store mode. The stores began to be enlarged from 1907 on, from three-story buildings to five-story buildings. From the beginning of the 1920s they were built even bigger: two stories underground, seven stories aboveground. At the same time the variety and quantity of goods was expanded. The scale of operations and the expanded lines of goods prompted a more rational and efficient organization of the structural setup, and a structure organized by functions and by different goods came to be introduced. As regards the latter, for example, in 1917 Shirokiya divided its goods into fabrics and general merchandise, then made each of these divisions a self-supporting system. ${ }^{13}$ In 1918 the Matsuzakaya Store in Nagoya introduced the same system. ${ }^{14}$

The display method became the common form of presenting articles for sale, and strategies to promote sales took on a variety of forms. More aggressive use was made of public notices and advertising activities, of shop-window and interior decorations, of improved lighting, of more types of equipment and facilities within the shops, of special sales and clearance sales at uniform prices, of telephone sales, and of mail-order sales. Beside sales tactics, other strategies to provide services were also adopted: the staging of special events; the sale of gift certificates; the provision of vehicles to transport customers to and from train stations; the setting up of a delivery service. Young women came to be hired as shop assistants, and even a new category of worker was created: the telephone switchboard operator.

${ }^{12}$ Ibid., pp. 42-63; also see Kojirō Hoshino, ed., Hibi Ōsuke (Hibi Ôsuke Biography Publication Society, 1951).

${ }^{13}$ Shirokiya Co., Ltd., Shirokiya sanbyakunen shi [Three hundred years of Shirokiya] (1957), p. 663.

${ }^{14}$ Matsuzakaya Co., Ltd., Shinpan tenshi gaiyō [Outline of the store's history, new edition] (1964), p. 138. 
Thus, by around 1910 the retail trade form known as the department store had firmly established itself, and the change in the form of trade was accompanied by a change in the form of enterprise as well, so that by 1910 all the former dry goods stores had adopted the form of joint-stock companies. Still, if we except Mitsukoshi, which started off fairly much as a professional-manager-run enterprise despite its close connection with the House of Mitsui and those connected with that House, these dry-goods-store-derived department stores still retained the nature of individually managed family enterprises deeply tinged with traditional elements from their dry-goods-store days. Even though the changeover in the form of trade had been effected by personnel within the companies, and even though this had been carried on by graduates of higher-education schools and personnel hired from outside the old networks, in nearly all cases friction between the old and the new was generated, and the changeovers were not by any means carried out without any problems or hitches. As a result, some of the old businesses experienced serious management problem and it took a long time for them to recover. ${ }^{15}$

During this period of their formation the department stores retained their traditional patterns in regard to their customers, as well. "Shirokiya's business was overwhelmingly with the daimyos, and even after the Meiji Period began they were catering to the 'nobility of daimyo descent' circles. Mitsukoshi, if anything, was catering to the propertied merchant and artisan classes and the peers descended from court nobles originally from the Kyoto area; Daimaru was popular with the 'downtown crowd,' what are nowadays referred to as the proletarian, ordinary citizens; most of Takashimaya's business was with the families of the princes connected with the Imperial Household Department, while Matsuzakaya had a monopoly on robes for the monks of the various religious sects and on the accessories for shrines and temples. Thus they all seemed to have extremely clear particular characteristics." 16 In the 1910 s, industrialization and urbanization

${ }^{15}$ See Kazutoshi Maeda, "Wagakuni hyakkaten no bokkō to kakuritsu" [The sudden rise and solid establishment of department stores in out country], Keizai ronsh $\bar{u}$ no. 12 (Daitō Bunka Daigaku Keizai Gakkai, 1970) and "Nihon ni okeru hyakkaten no ichikeifu" [Family trees of department stores in Japan], Komadai keiei kenkyū 2/3-4 (Komazawa University Institute of Business Management, 1971).

${ }^{16}$ Hachisaburō Tsukamoto, Hyakkaten omoidebanashi [Department store reminiscences] (Department Store Reminiscences Publication Society, 1950), pp. 39-40. 
were accelerated before and after World War I, especially in Tokyo, where overpopulation within the city limits and the overflow of the population into surrounding areas beyond the city limits was beginning to occur. In the midst of changes to city structures, a rise in income levels, and the development of means of transportation, department stores solidified their foundations by targeting the upper levels of customer strata, even as they gradually lost more and more of their traditional features.

\section{REFORM AND LIMITATIONS}

After the economic panic of 1920 that came as a reaction to the end of World War I, the department stores switched to a policy of targeting a plurality of indeterminate customer strata. Mitsukoshi, which had already in 1919 embarked on prices sales of such essential goods as kimono fabrics, general merchandise, and foodstuffs as a means of counteracting high prices, established a "market" to serve as a place of permanent bargain-price sales of utility goods with the aim of regulating prices (this was continued until 1922). The merchandise sold there included cotton goods, general merchandise, tableware, foodstuffs, kitchenware, and Western clothing; such things as biscuits, corned beef, sugar cubes, bread, pencils, laundry soap, and slippers were sold at 20 to $30 \%$ off the market prices. ${ }^{17}$ Shirokiya also established in 1922 a permanent bargain-sales section offering kimono fabrics and general merchandise. Discount sales and bargain sales at the department stores also extended to tabi, soap, confectionery, and other items that were of well-known brands and that had fixed prices. At this time, also, in general merchandise, overseas-made goods, which had formed a high proportion of the items on sale, were being replaced more and more by domestically made goods. The trend towards popularization increased noticeably after the Great Kantō Earthquake of 1923. The earthquake caused considerable damage to department stores in Tokyo. Mitsukoshi, Shirokiya, and Matsuya suffered capital losses; Shirokiya in particular was slow in recovering from its financial difficulties. Nevertheless, every department store was quick to put up temporary stores where daily necessities and utility goods were sold at low prices. It was from this time on that depart-

${ }^{17}$ Mitsukoshi Dry Goods Store, Mitsukoshi 12, no. 9 (1923), pp. 9 and 29. 
ment stores took on the character of distribution organs catering for the general consumer masses.

Their merchandise lines were expanded in step with their popularization, but this was also connected with the trend toward larger stores and more numerous stores. In the year before the earthquake, in 1922, the floor space of Mitsukoshi was 8,961 tsubo, Shirokiya had 2,507 tsubo, Matsuya had 1,500 tsubo, Matsuzakaya (Ueno) had 1,800 tsubo, and Takashimaya (Tokyo) had 500 tsubo. After the earthquake "the grand scale" became part of the recovery process, and so we find that in 1932 Mitsukoshi had 16,177 tsubo of floor space, Shirokiya 13,047 tsubo, Matsuya (moved to a Ginza location) had 13,826 tsubo, Matsuzakaya (Ueno) had 12,037 tsubo, and Takashimaya (Tokyo) had 1,694 tsubo. Outside of Tokyo, only the Takashimaya Nankai store in Osaka, which opened all its buildings in that same year of 1932, had more than 10,000 tsubo of floor space. ${ }^{18}$

While a trend towards opening many stores was in evidence earlier, it was in this period that one department store after another established stores, branch stores, and branch offices in one and the same city (not including the temporary stores built after the earthquake), in other principal cities, and even overseas. Though Shirokiya had lagged behind in rebuilding its main store, it was particularly active in this regard; following the principle of dispersal, it went ahead with development of a network of branch stores that concentrated on foodstuffs, kimono fabrics, and cotton goods, and general merchandise and that always included cafeterias within the stores. In 1931 Shirokiya had 14 such branch stores. ${ }^{19}$ In 1931, too, Takashimaya began a chain of branch-store-style uniform-price shops connected with its department stores; within the single year it had opened 51 such shops. In 1933 it made the uniform-price shops division an independent division, and in 1938 it hived this division off completely, in the form of Marutaka Kin'itsu Store, Inc. ${ }^{20}$ The move towards large numbers of stores was a response to increased urbanization and the development of transportation within the cities, and some stores began to appear in the terminals of railways.

18 Takashimaya Co., Ltd., Takashimaya 150nen shi [The first 150 years of Takashimaya] (1982), p. 114.

${ }^{19}$ Shirokiya Co., Ltd., Three Hundred Years of Shirokiya, p. 667.

${ }^{20}$ Takashimaya Co., Ltd., The First 150 Years of Takashimaya, pp. 111-12. 
In the process of the move toward popularization by the department stores, new types of department stores appeared on the scene. These were the department stores built and owned by electric railway companies in the terminals of their railway lines. The first of this kind appeared in 1929 with the opening of Hankyū Department Store (first called Hankyū Department Store Division before it became independent). It originated from the Shirokiya store in Umeda, Osaka, which Hankyū had leased; then in 1925 Hankyū directly managed a "market" dealing in foodstuffs and general merchandise for daily use, and it used this market as a stepping stone into the department store business. Targeting as its customers the people living near its railway line and salaried worker commuters, Hankyū put heavy emphasis on its cafeterias/small restaurants and restricted its merchandise to foodstuffs and general merchandise whose selling point was their utility; for the first two years of its operations it did not stock any high-class kimono fabrics in the store. The concept of a department store in a railway terminal was the brainchild of Ichizō Kobayashi, manager of the electric railway company. From the time of the market operations (1925) he had directly managed factories manufacturing confectionery and textile general merchandise; after the establishment of the department store, he not only built factories to produce foodstuffs and pharmaceuticals but also moved into the wholesale stage by establishing the Osaka Bussankan (Osaka Products Hall) in 1934. In other words, he pursued vertical integration. While there were also examples in the dry-goods-derived line of department stores of owners who moved into the manufacture of foodstuffs and furniture and the like, in the case of Hankyū this occurred as a result of Kobayashi's idea of "selling [goods] at lower prices than anywhere else does."21

One after another, department stores and retail "markets" modeled on the Hankyu store and managed by electric railway companies appeared in the terminals of railways. In the Osaka-Kobe area alone, in 1932 there appeared the Keihan Department Store; in 1933, the Hanshin Mart; and in 1936 in subsequent years, Daiki (later Kintetsu) Department Store and Daitetsu (later Kintetsu) Department

${ }^{21}$ Hankyū Department Stores, Inc., Kabushikigaisha Hankyū Hyakkaten 25nen shi [The first 25 years of Hankyü Department Stores] (1976), 2nd edition. 
Store. In the Tokyo area there was Keihin Department Store in 1933, Tōyoko (present-day Tōkyū) Department Store in 1934, and Musashino Department Store (a branch of the Keihin Department Store that was purchased by the Musashino Railway; present-day Seibu Department Store) in 1940. ${ }^{22}$ Among the dry-goods-derived department stores that built branch stores in the terminals of private railway lines were Shirokiya (a branch office at Tenroku in Osaka in 1928), Matsuya (the Asakusa store in 1931), and Takashimaya (the Osaka Nankai store in 1932).

In the 1920s and 1930s, along with the train-station department stores, new department stores appeared in the large cities and even in regional cities that had started from existing retailers, especially dry goods stores. The most representative example of this type of store is Isetan, which moved from its location in Hatago-chō, Kanda, to Shinjuku, where it built a store with 16,500 square meters of floor space in 1932.

Thus department stores increased throughout the country, but not much is known clearly about the details. It is known that there were 35 different companies involved in department store trade in $1931 ; 23$ as for the number of incorporated businesses, we know that in 1921 there were 8 (all of them joint-stock); in 192514 (12 joint-stock); in 193029 (28 joint-stock); and in 193551 (49 joint-stock). ${ }^{24}$

According to a survey conducted by Tokyo City from November 1931 until November the following year, there were 36 department stores operating within the city limits (corresponding to the wards portion of present-day Tokyo), and their sales made up $25 \%$ of the total sales made by the 142,000 retailers (of all sizes) operating in the city. Their share of sales of certain items was extremely high: $61.6 \%$ in fabrics and clothing; $50 \%$ or higher in fittings and furniture, knickknacks and haberdashery, toys and play equipment; and $30 \%$ or higher in footwear, umbrellas and other raingear, musical instruments, clocks, and jewelry-groups of items that customers shopped

${ }^{22}$ Tsunehiko Yui, ed., Tsutsumi Yasujïrō [Biography of Yasujirō Tsutsumi] (Libroport, 1996), pp. 299-301.

${ }^{23}$ Yasuaki Suzuki, Shōwa shoki no kourishō mondai [Retail trader problems in early Shōwa] (Nihon Keizai Shinbunsha, 1980), p. 85.

${ }^{24}$ Nihon teikoku tōkei nenkan [Statistical annual of the Japanese empire] No. 42 (1924), No. 46 (1927), No. 51 (1932), and No. 56 (1937). 
around before they bought. But even in foodstuffs their share reached $9.2 \% .{ }^{25}$ Now, while this figure of $25 \%$ may be considered too high in view of the figure of $10 \%$ given by the extraordinary national survey of 1939 that was mentioned earlier, according to a survey conducted in 1934 by the Tokyo Business Guilds Federation the figure of $24.28 \%$ was given. ${ }^{26}$ In any case these figures show that the department stores were carrying out an important role as distribution organs serving the masses of the populace. The Tokyo City survey also made a management comparison between the department stores and other retail traders, and it concluded that not only did the former show superiority in the rate of outlay for buying prices and sales, but they also were twice as fast in the turnover rate of their goods. ${ }^{27}$

Department stores' way of purchasing stock and their sales activities also underwent change. If we look, for example, at their purchases of kimono fabrics, which was the main stock-in-trade of the department stores, we see that before the earthquake they had two main ways of obtaining their goods: purchases from producing centers and purchases from wholesalers. The wholesalers thus tended to regard their trade with the small and medium-sized retail shops as more important, since it brought them more profit. But because these small and medium-sized retailers were slower in recovering from the effects of the earthquake, the kimono fabric wholesalers started to attach more value to their transactions with the department stores. This also proved to be of great advantage to the department stores, who, faced with an urgent need for more stores and more warehouses, were able to make good use of the funding capacities and storage functions of the wholesalers. Transactions between the department stores and the wholesalers thus increased. ${ }^{28}$ Sales activities were entered into with enthusiasm, in line with the move toward targeting the mass of the population; measures to improve sales were greatly diversified; competition among the different department stores became

${ }^{25}$ Tōkyō Shiyakusho [Tokyo City Hall], Tōkyō-shi-Shōgyō chōsasho [Tokyo City, a survey of commercial businesses] (1933), p. $\tilde{5}$ l.

${ }^{26}$ Yūkichi Mizuno, Hyakkaten ron [On department stores] (Nihon Hyōronsha, 1937), p. 39.

${ }^{27}$ Tokyo City Hall, Tokyo City, p. 51.

${ }^{28}$ Takashimaya Co., Ltd., The First 150 Years, p. 102. 
fierce. By the end of the 1920s the antagonism between department stores and small and medium-sized retail shops over low prices, gift certificates, sales in hired halls, and similar practices became a social problem in Japan. And in the early 1930s we start to see branch stores being disposed of and some of the companies going bankrupt.

Prior to World War II the department stores achieved growth and expansion, and they set their form of business on a solid footing. I cannot go into a long discussion of the matter here; Table 1, while inadequate, is an attempt to show the business results of the major companies that were leaders in the department store retail trade before the war, covering an amount of time extending over a period of recession, a semi-wartime period, and part of the wartime period. From the table it is possible to see that Mitsukoshi maintained its overwhelmingly dominant position throughout; that Takashimaya achieved an extremely high profit ratio before the Great Depression; that right from the first year of Hankyū's establishment its profits surpassed those of Shirokiya, and they grew rapidly; that Shirokiya continued in a state of stagnation for a long time.

Let me say something here about the management policies of Shirokiya. Faced with financial difficulties after the Great Kantō Earthquake, the company embarked on management reforms in 1932. In the area of laying in stock, it adopted, as "a means of supplying an abundance of goods without the need for funds" and under the name of "Special Cash Stocking," a consignment sales system. In September of that year such stock would come to $78.8 \%$ of the total amount of stock taken in. But while this method succeeded as a way to gain short-term business recovery, gradually the company found it harder to engage in transactions with the best wholesalers, and the quality of the company's merchandise and its sales fell. As a result, in 1933 the company stopped using this method except in a very few areas such as foodstuffs. The consignment sales system stimulated some interest in other department stores at the time, but it was not widely adopted before the war. ${ }^{29}$

To raise the funds needed in the expansion process, department stores soon ran out of internal sources of funds and began to rely on such methods as issuing new shares, issuing debenture bonds, or long-term borrowing of money from financial institutions. Still, as of

${ }^{29}$ Shirokiya Co., Ltd., Three Hundred Years, pp. 400-402, 491-93. 
Table 2. Ranking by Sales Turnover of Postwar Retail Enterprises (Unit: 100,000,000 yen)

\begin{tabular}{|c|c|c|c|c|c|c|c|c|c|c|c|c|}
\hline \multirow[b]{2}{*}{ Rank } & \multicolumn{2}{|c|}{1950} & \multicolumn{2}{|l|}{1951} & \multicolumn{2}{|l|}{1952} & \multicolumn{2}{|l|}{1953} & \multicolumn{2}{|l|}{1954} & \multicolumn{2}{|l|}{1955} \\
\hline & Name & Sales & Name & Sales & Name & Sales & Name & Sales & Name & Sales & Name & Sales \\
\hline 1 & Mitsukoshi & 118 & Mitsukoshi & 170 & Mitsukoshi & 203 & Mitsukoshi & 249 & Mitsukoshi & 245 & Mitsukoshi & 249 \\
\hline 2 & Takashimaya & 116 & Matsuzakaya & 157 & Matsuzakaya & 182 & Matsuzakaya & 206 & Daimaru & 201 & Daimaru & 246 \\
\hline 3 & Matsuzakaya & 104 & Takashimaya & 152 & Takashimaya & 180 & Takashimaya & 194 & Takashimaya & 197 & Takashimaya & 208 \\
\hline 4 & Daimaru & 92 & Daimaru & 116 & Daimaru & 135 & Daimaru & 165 & Matsuzakaya & 194 & Matsuzakaya & 201 \\
\hline 5 & Hankyū & 37 & Hankyū & 64 & Hankyū & 71 & Töyoko & 70 & Hankyū & 89 & Töyoko & 108 \\
\hline 6 & Shirokiya & 24 & Tōyoko & 40 & Tóyoko & 56 & Sogō & 65 & Töyoko & 82 & Hankyū & 98 \\
\hline 7 & Tōyoko & 20 & Shirokiya & 38 & Shirokiya & 52 & Hankyū & 64 & Isetan & 67 & Isetan & 78 \\
\hline 8 & Isetan & 19 & Isetan & 25 & Sogō & 43 & Isetan & 43 & Sogō & 60 & Matsuya & - \\
\hline 9 & Sogō & 13 & Matsuya & 21 & Isetan & 33 & Marubutsu & 26 & Marubutsu & 28 & Sogō & 60 \\
\hline 10 & Marubutsu & 13 & Marubutsu & 17 & Matsuya & 24 & - & - & - & - & Shirokiya & 53 \\
\hline
\end{tabular}

\begin{tabular}{|c|c|c|c|c|c|c|c|c|c|c|c|}
\hline \multirow[b]{2}{*}{ Rank } & \multirow{2}{*}{$\begin{array}{l}1956 \\
\text { Name }\end{array}$} & \multirow{2}{*}{$\begin{array}{l}1957 \\
\text { Name }\end{array}$} & \multirow{2}{*}{$\begin{array}{l}1961 \\
\text { Name } \\
\end{array}$} & \multicolumn{2}{|l|}{1969} & \multicolumn{2}{|l|}{1972} & \multicolumn{2}{|l|}{1978} & \multicolumn{2}{|l|}{1983} \\
\hline & & & & Name & Sales & Name & Sales & Name & Sales & Name & Sales \\
\hline 1 & Daimaru & Mitsukoshi & Daimaru & Mitsukoshi & 1,507 & Daiei & 3,052 & Daiei & 9,405 & Daiei & 12,519 \\
\hline 2 & Mitsukoshi & Daimaru & Mitsukoshi & Daimaru & 1,440 & Mitsukoshi & 2,924 & Itō-Yōkadō & 4,886 & Itō-Yôkadō & 8,609 \\
\hline 3 & Takashimaya & Takashimaya & Takashimaya & Takashimaya & 1,297 & Daimaru & 2,131 & Seiyū Store & 4,818 & Seiyū & 6,964 \\
\hline 4 & Matsuzakaya & Matsuzakaya & Matsuzakaya & Daiei & 1,200 & Takashimaya & 1,994 & Mitsukoshi & 4,693 & Jusco & 6,951 \\
\hline 5 & Tōyoko & Tōyoko & Tōyoko & Matsuzakaya & 1,031 & Seiyū Store & 1,668 & Jusco & 4,448 & Nichii & 5,497 \\
\hline 6 & Hankyū & Hankyū & Hankyũ & Seibu & 845 & Seibu & 1,550 & Daimaru & 3,912 & Mitsukoshi & 5,220 \\
\hline 7 & Isetan & Isetan & Isetan & Seiyū Store & 800 & Jusco & 1,550 & Nichii & 3,496 & Takashimaya & 4,764 \\
\hline 8 & Matsuya & Sogō & Seibu & Jusco & 750 & Matsuzakaya & 1,493 & Takashimaya & 3,493 & Daimaru & 4,681 \\
\hline 9 & Sogō & Matsuya & Sogō & UNY & 650 & Nichii & 1,442 & Seibu & 3,097 & Seibu & 4,559 \\
\hline 10 & Shirokiya & Shirokiya & Matsuya & Isetan & 647 & UNY & 1,264 & Matsuzakaya & 2,744 & UNY & 3,861 \\
\hline
\end{tabular}

\begin{tabular}{|c|c|c|c|c|c|c|c|}
\hline \multirow[b]{2}{*}{ Rank } & \multicolumn{2}{|l|}{1985} & \multicolumn{2}{|c|}{1990} & \multicolumn{2}{|l|}{1995} & \multirow{2}{*}{ Sources: Quarterly issues of Mitsubishi Keizai Kenkyūjo, ed., Honpō jigyō seiseki bun- } \\
\hline & Name & Sales & Name & Sales & Name & Sales & \\
\hline 1 & Daiei & 13,736 & Daiei & 18,420 & Daiei & 25,034 & seki [Analysis of business resurts in Japan]; El]1 inlya, Genaar Ninon koun kene \\
\hline 2 & Itō-Yōkadō & 9,532 & Itō-Yōkadō & 13,551 & Itō-Yōkadō & 15,449 & senryaku shi [A history of retail management strategies in modern Japan] \\
\hline 3 & Seiyū & 7,655 & Seiyū & 10,484 & Jusco & 12,020 & (Kōyō Shobō, 1985), pp. 204-205; Nikkei Ryūtsū Shinbun, ed., Rankingu \\
\hline 4 & Jusco & 7,612 & Jusco & 9,953 & Mycal & 10,528 & ryūtsū kakumei [Ranking the distributive revolution] (Nihon Keizai Shin- \\
\hline 5 & Nichii & 5,772 & Seibu & 9,853 & Seiyū & 10,233 & bunsha, 1987), pp. 24 and 27; and Nikkei Ryūtsū Shinbun, ed., Ryūtsū \\
\hline 6 & Mitsukoshi & 5,684 & Mitsukoshi & 8,666 & Takashimaya & 8,919 & keizai no tebiki [Handbook of distribution economics] (Nihon Keizai Shin- \\
\hline 7 & Seibu & 5,353 & Takashimaya & 7,676 & Mitsukoshi & 7,565 & bunsha), 1992 and 1997 editions. \\
\hline 8 & Takashimaya & 5,015 & Nichii & 7,081 & UNY & 6,398 & \\
\hline 9 & Daimaru & 4,960 & Daimaru & 6,066 & Seibu & 6,349 & ars $1950-55$ the rankings are taken from the first source liste \\
\hline 10 & UNY & 4,123 & Marui & 5,658 & Daimaru & 5,085 & above. \\
\hline & & & & & & & 2. Nichii is now called Mycal. \\
\hline
\end{tabular}


1933 some of the companies, for instance Takashimaya, had not issued any debenture bonds or borrowed any money. When it came to new share issues, too, well, in 1931 Mitsukoshi, and in 1940 Shirokiya, listed shares on the futures market of the Tokyo Stock Exchange; in many cases, even if shares were offered for public subscription, restrictions were put on who could buy them: employees, a certain few customers, or people the department store bought goods from. When we look at the rates of ownership of shares, we see that in $192735.5 \%$ of Daimaru shares were owned by the Shimomura family; in 1929 the Furuya family owned $36.7 \%$ of Matsuya, and the Iida family owned $45.6 \%$ of Takashimaya. Thus the percentage of shares owned by one family or a family and close relatives was high in these cases; in the case of Shirokiya, however, the Ömura family held only $6.8 \%$ of the shares. ${ }^{30}$ As a general rule, however, department stores still strongly retained the characteristics of family enterprises.

FROM RECOVERY AND GROWTH TO MATURITYAND STAGNATION

\section{THE ARRIVAL OF THE "GOLDEN AGE"}

By 1955 department stores had, on the whole, reached their prewar levels, though this does not mean that all of the individual companies made a fresh start after the war on what they had from prewar days. For the GHQ of the Occupation forces requisitioned many department store buildings between 1945 and 1947. Matsuya's main store on the Ginza and its two Yokohama stores were taken over in toto, as was Sogō's Osaka store. Since requisitioned properties were held by GHQ until 1953, when it was stopped, great disparities in the recovery rates of different department stores resulted. During this period Seibu completed its 11,000-square-meter store in Ikebukuro (construction began in 1951 and was over in 1953); other stores were remodeled or added on to, such as Matsuzakaya's Ueno and Ginza stores and Takashimaya's Nihonbashi store. In 1953 Hankyū opened a store in Ōi, and in 1954 Daimaru opened its store in Tokyo Station-Kansai-based department stores had successfully made inroads into

${ }^{30}$ The information on Daimaru was obtained from the company's register of shareowners; information on the other companies was obtained from Shinzō Matsuda, Depaatomento stoa [Department stores] (Nihon Hyōronsha, 1931), p. 147. 
Tokyo. Regional department stores also were reopened, or opened for the first time, in this same period. The composition of merchandise, as well, approached the prewar levels, and competition among the department stores intensified, thanks to the "bargain selling" of the Kansai-based department stores.

When the first Department Store Ordinance was revoked in December 1947, department store activities became regulated by the Anti-Monopoly Law, which had been promulgated in April of that same year. The watchdog of the latter law, the Fair Trade Commission, in 1952 informed department stores throughout the country that such practices as unreasonable return of goods, or forcing manufacturers or suppliers to send their employees to work as salespersons in the department stores, were unfair trade methods prescribed by the AntiMonopoly Law. In 1954 it made public a special designation of unfair trading methods used by the department stores, listing unreasonable return of goods, unfair discounting, unfair laying in of stock on consignment, and the requirement that salespersons be dispatched to the department stores. The series of stronger regulatory steps taken against the department stores was due not only to lobbying by the small and medium-sized retailers but also to a fairly large extent by the wholesalers. This was but one indication of the fact that the business operations of wholesalers were generally weakened after the war.

To make up for shortages of funds and personnel and to reduce risk in the recovery period, department stores utilized the various systems that had existed before the war: the returning of goods, the dispatching of salespersons, the laying in of goods on consignment, etc. But because these practices differed from the prewar practices both quantitatively and qualitatively, they caused friction with the wholesalers and other suppliers of goods. During the recovery period new trade practices came into being between department stores and their suppliers, and these would long persist in the form of a consignment sales system and a shop worker dispatching system. ${ }^{31}$ By making these systems a fixed feature of business arrangements, the department stores managed to extend their lines of merchandise while shifting more

${ }^{31}$ Mika Takaoka gives a detailed analysis in her article "Sengo fukkōki no Nihon no hyakkaten to itaku shiire" [Japanese department stores and laying in of consignment stock in the postwar recovery period], Keieishigaku [Japan Business History Review] 32, no. 1 . 
and more risk onto suppliers. In 1955 the composition of the merchandise sold in department stores as a whole was: clothing, $50 \%$; then personal effects, foodstuffs, and household goods in that order. ${ }^{32}$ But the merchandise making up the various areas were constantly changing as a result of the changes in people's lifestyles after the war (the classic example being, of course, the switch from kimonos to Western clothing), and department stores coped with this situation by laying in stock on consignment.

As department stores became more and more active, conflicts with small and medium-sized retailers and with wholesalers intensified, as I mentioned earlier, so much so that in 1956 the second Department Store Ordinance was put into effect. This act regulated department stores until 1974, when the Large-Scale Retail Stores Law went into effect. The general trends of the various companies during this period seen in terms of their sales are shown in Table 2. The table shows the rapid strides made by Daimaru and the steady progress made by Tōyoko (hereafter, Tōkyū), Hankyū, and other electric-railway-related department stores.

From 1956 through the first half of the 1960s, department stores enjoyed the period of their greatest development, what might be called their "golden age," without much attendant reform in business management. Newly opened stores included Meitetsu Department Store (Nagoya), opened in 1954; Sukiyabashi Hankyū (Tokyo), 1956; Yokohama Takashimaya, 1957; Sogō's Tokyo store (Yūrakuchō), 1957; Hanshin Department Store (Osaka), 1957; Mitsukoshi's Ikebukuro store, 1957; Tokyo Marubutsu (now Parco) in Ikebukuro, 1957; Tōbu Department Store (Ikebukuro), 1962; Odakyū Department Store (Shinjuku), 1962. The entry into the market by electric-railway-related department stores was conspicuous. During this same period the number of department stores derived from earlier dry goods stores or general food stores increased in regional areas, thus bringing about an expansion of business floor space and an increase in total sales figures.

The one notable feature of this growth period was the development of department stores in the subcenters of metropolises and in train terminals. This was especially true in Tokyo. With the population growth

\footnotetext{
${ }^{32}$ This information is largely based on Japan Department Stores Association materials (information on Hankyū is from its The First 25 Years, p. 420).
} 
in the hinterlands and the development of means of transportation, department stores located in Shinjuku and Ikebukuro were blessed with growth conditions. Management policies in the dry-goods-storerelated department stores and those in the electric-railway-related department stores differed, the result of location and other conditions. In the former the center of gravity lay in the clothing sector, and this meant high seasonal fluctuations in sales; the latter, however, placed more emphasis on foodstuffs and other utility goods, and as a result seasonal fluctuation rates in sales were fairly evenly balanced. While these differences existed, still, as far as the composition of merchandise in the latter was concerned, once they set their minds on becoming full-fledged department stores in the period of growth, they increased the number of suppliers they dealt with and their merchandise were in no way inferior to those sold in the dry-goods-related department stores.

The composition of goods on offer in department stores as a whole changed in response to changes in consumption. If we take 1955 as the index of 100 and compare things with how they were in 1962, we find that during this period clothing increased 2.8 times, but its share of the total range fell from $47 \%$ to $45 \%$; foodstuffs also increased, by about 3 times, but its share fluctuated around 16\%; general merchandise increased 2.9 times, but it more or less maintained its share of $18 \%$. The item that increased the most and whose share of the total composition rose very much was household goods, especially durable consumer goods such as electrical household appliances and indoor furniture; during this period this item increased 4.2 times, and its share rose from $9.7 \%$ to $14.1 \% .^{33}$

Finally, in each of the different areas department stores aimed at a range of goods that catered to the demand for high-quality goods and for diversity.

On the basis of fluctuations in the ranking of department stores in terms of sales during this period of postwar growth (see Table 2, which gives a partial picture of the situation), a few things worthy of note can be pointed out. The first is that Daimaru replaced Mitsukoshi at the top of the list in 1956, and again in 1961 (where it remained until 1968). Secondly, of the top ten stores in 1955, eight were in the dry goods family tree, and only two were connected with private rail-

${ }^{33}$ Ibid. 
ways, but then Seibu joined the top ten in 1958 and slowly rose in ranking after that. Thirdly, Shirokiya, which had been struggling for years, became affiliated with Tōkyū in 1956 (becoming Tōkyū Nihonbashi). Mitsukoshi, owing to its management policy of steadiness and conservatism in use of funds and its stress on goods turnover, continued to experience lower sales growth than the department stores as a whole, but they maintained a net-worth ratio of 40 to $50 \% .^{34}$

Isetan followed a rather different course from the companies that were setting up numerous stores (Mitsukoshi with 11 stores, Daimaru with 4 , Takashimaya with 3 , Matsuzakaya with 5 , and so on); while it did have a second store in Tachikawa, it decided to concentrate on Shinjuku, where its merchandizing pioneered the youth market, it build the first parking-lot building in the industry, made joint use of gift certificates with regional department stores, and engaged in joint stock-purchasing and joint sales through tie-ups. By these and other innovative approaches it achieved rapid growth. ${ }^{35}$

Among the electric-railway-related department stores, the Sukiyabashi Hankyu store was the first one to become specialized by means of a market segmentation strategy when it remodeled itself on the theme "a department store specializing in ladies' wear." Seibu, which had made such rapid progress in a short time, switched from being a trainstation department store in 1960 catering to the masses with an emphasis on foodstuffs and cafeterias, to a full-fledged general department store equipped with sections for household furniture, household goods, clothing, and sundry personal effects, and at the same time it embarked on new operations, aiming at the formation of a new type of distribution enterprise. The feature common to all the electric railway department stores was their aggressive move into the supermarket business; while some of the traditional department stores also entered into the supermarket business, it was the electricrailway-related ones that were to enjoy success later.

${ }^{34}$ Junjirō Takahashi, Mitsukoshi sanbyakunen no keiei senryaku [Mitsukoshi's business strategies over 300 years] (Sankei Shinbunsha, 1972), pp. 165-69.

${ }^{35}$ Takao Tsuchiya, Nidai-Kosuge Tanji [Two generations: Tanji Kosuge], vol. 2 (Isetan Co., Ltd., 1972), pp. 111-12. 


\section{GROPING TOWARDS INNOVATION IN BUSINESS FORM}

From the mid-1960s until 1974 the sales turnover of department stores increased at a higher rate than that of the retail trade as a whole, but their overall share was relatively low. It could be that things changed in the midst of the advent of "the abundant age" because of rising prices from 1970 on, but the changes in the consumption structure of this period were accompanied by greater emphasis on high-quality goods, diversification, and individualization. To this can be added urbanization and the advance in motorization that began in the second half of the 1960s, which greatly altered the distribution environment. The new general supermarket chains and specialty stores grew because they were good at adjusting to the changes, while the reactions of department stores tended to be slow. At the heart of this slowness to change can be found the conviction among department store managers that supermarkets and department stores were completely different forms of business, with department stores being the most excellent form of retail trading, and with a consequent feeble awareness of danger ahead. ${ }^{36}$ The problem was that they saw the general supermarkets as just another form of retail business, and did not envision that they would push ahead with the formation of groups from the mid-1960s on, engaging in diversification into such areas as home purchasing, leisure activities, and restaurants, as well as in full-line specialty stores, convenience stores, and the like, and carrying out a strategy of expansion as enterprises. Internally, as well, the reliance on the systems that had become entrenched in the recovery period, that of having salespeople dispatched to work in their stores and that of laying in stock on consignment, gradually brought on a lowering of the merchandising abilities of department stores and their ability to determine prices. But the increase in sales did not allow these problems to surface during this period.

Department store floor space grew by an annual average of $8 \%$ between 1963 and 1973, with 155 new stores being built during this time. Around the year 1970 stores wee built on unprecedented scales in the large metropolises: Odakyū, Isetan, Seibu, Mitsukoshi Nihonbashi all

\footnotetext{
${ }^{36}$ Editorial Board of The Economist, ed., Shōgen-kōdo seichōki no Nihon [Bearing witness to Japan during the high growth period], vol. 2 (Mainichi Shinbunsha, 1984), p. 54.
} 
had floor spaces of 50,000 square meters or more, thus ushering in the "age of giant stores." As well, new stores continued be built one after another in the suburbs of the large cities, in satellite cities, and in regional cities, but these were in shopping centers and train stations. In 1969 the Tamagawa Takashimaya Shopping Center, opened by the Takashimaya Group (formed around Yokohama Takashimaya) using Tōshin Kaihatsu as their developer, came into being as the first full-fledged suburban shopping center, and it proved to be a success. It had a total floor space of 64,741 square meters, a trading area of 28,759 square meters, parking space for 1,000 vehicles, and room for 130 tenant shops; the core of the center was the Yokohama Takashimaya Tamagawa store. ${ }^{37}$ It stood as a representative example of the innovation that would take place during this period in strategies regarding the location of department stores. In the regional cities, meanwhile, the powerful department stores became larger and larger and some of the weaker ones went bankrupt, and disparities between the two poles grew greater and greater.

Strategies looking for "economies of scale" also appeared in the shape of an increasing formation of groups. The joint-laying-in-of-stock mechanism that was seen in the preceding period was formed again in this period, with Seibu and Matsuya the chief exponents. While the joint-laying-in-of-stock mechanism was no more than a business tieup, in the 1970s some of the enterprises taking part made capital tieups with the core department store as well. The concentration of laying-in activities took the form of the introduction of a system in which, in those department stores that had gone in for building many stores, the laying in of stock was concentrated in the main store. Mitsukoshi, which already was following this course of action, was followed by Seibu in 1962, and in 1963 by Takashimaya, which set up a merchandise headquarters and began merchandise development and concentrated laying in of standard merchandise. In merchandising, famous-brand goods were imported from overseas and the development of private brands was promoted; department stores in the large cities, in particular, attempted to lift their prestige by a strategy of differentiation based on brands. City department stores like Mitsukoshi and Takashimaya developed strategies aimed at high-quality goods. But Mitsukoshi, Daimaru, Takashimaya, and Matsuzakaya continued

${ }^{37}$ Takashimaya Co., Ltd., The First 150 Years, pp. 215-16. 
on a downward trend in the clothing sector, with clothing's share of sales figures constantly falling, while their service and other sectors increased their shares. This was the result of a phenomenon that occurred during this time, that of consumers "shying away from spending on things." In addition to all this, department stores at this time also ventured into such things as specialty chain stores, supermarkets, variety stores, and catalogue sales, thus diversifying their forms of business.

It was at this time that companies in the retail trade other than department stores made it into the list of the top ten retailers in terms of sales. Though not shown in Table 2, in 1963 the general supermarket Daiei showed up in the top ten, and from then until 1979 others also joined the list: Seiyū Store (now Seiyū), Jusco, UNY, Nichii (now Mycal), and Itō-Yōkadō. In 1972 Daiei even took over first place from Mitsukoshi. As a form of business the department stores were now in their maturity, and viewed from the enterprise level they had entered a turning point in their existence. The only one that expanded and grew at this time was Seibu. When the Seibu Distribution Group was formed in 1963 (in 1985 the name was changed to Seibu Saison Group), Seibu became the core company, and it achieved rapid growth by pushing forward with the establishment of more stores and the enlargement of the Ikebukuro store. An affiliate of the group, Seiyū, grew by pushing ahead with building up its chain of stores, so that within one and the same group you had the unusual example of a department store and a general supermarket compatible with each other.

In the latter half of the 1970s department stores showed a temporary recovery, dubbed "the rehabilitation," when they slipped out of the sales slump at the end of the 1970s and through 1980. This was due to a boom that resulted from a strategy of "renewal, refreshment [i.e., freshening up], and remodeling." Typical examples of this were the Seibu Ikebukuro store, the Matsuya Ginza store, and the Isetan Shinjuku store. The Seibu Ikebukuro store, which had expanded to 54,000 square meters of sales floor space in 1975, endowed the department store with the function of a "town," introducing specialty shops and boutiques; to run them, management adopted a "shopmaster system" in which employees had the same authority and responsibilities as the owners of specialty shops. On the occasion of 
its freshening up of its Shibuya store in 1976, Seibu headed in the direction of specialization by realizing the concept of "a seven-tenths department store," then afterwards, in its Ikebukuro store, it created a new department store image, that of a "large store of specialties" that integrated merchandising. ${ }^{38}$

In the first half of the 1980 s, along with renewal, investment continued in new stores, not only by department stores in the large cities but also by those in regional cities. At the same time, however, unprofitable stores were continually being disposed of, or being turned into new forms of business. Reorganization among the department stores by means of grouping also went ahead, though, compared with the general supermarkets, with less enthusiasm and still some fluidity. While the department stores moved into mail order business and credit cards and pushed ahead with changing into a multiple form of business on the one hand, on the other they put more effort into merchandising, increased the share of foodstuffs in their lines of merchandise, and did more to promote the development of private brands, but in spite of all their efforts business results during this period fluctuated at a low level, with the result that the industry was called "a structural recession industry." And with good reason, for in this period we find Daiei buying up Takashimaya shares, the dismissal of the president of Mitsukoshi, the replacement of the president of Daimaru, the problem of Isetan's entertainment of sōkaiya (fixers of shareholders' meetings), the replacement of the president of Matsuzakaya-a series of scandals and happenings that pointed to the need for a reform of the managerial constitution of the aging department stores. These forces were to shake up the topmanagement heredity system that four of the oldest companies (excluding Mitsukoshi) had long continued to maintain as family enterprises. ${ }^{39}$

Reflecting the stagnation of the department stores, even the top rankings in sales turnover in the retail trade were being taken over by general supermarkets; thus, in 1983 five of the latter ranked higher than any of the department stores. On both the level of business

${ }^{38}$ Tsunehiko Yui, Sezon no rekishi [The history of Saison], vol. 2 (Libroport, 1991), pp. $61-64,66$.

${ }^{39}$ Hidemasa Morikawa deals with the case of Matsuzakaya in his Toppu manejimento no keieishi [Business history of top management] (Yühikaku, 1996). 
form and the level of individual enterprises, department stores were in obvious recession. Of all the department stores, it was Seibu that had been groping for a way to break out of the old department store mold, and that had grown big enough to rank second after Mitsukoshi in 1985. But when consumption hit rock bottom in 1985 and department stores headed for expansion, they increased their rate of sales growth very rapidly, ahead even of the general supermarkets. This was not the result of rebuilding their management structurally but of a response to consumption patterns in which people spent money on high-priced items and large items. In the second half of the 1980s Seibu directed its steps toward realizing corporate culture in the form of "an industry of integrated information for daily life" and developed multiple operations involving both department store operations and operations outside of strictly department store operations. ${ }^{40}$ In 1987 it eclipsed Mitsukoshi in sales and became the top department store. During this bubble economy department stores would develop new expansion strategies, setting up branches in Southeast Asian countries and the like, but once the bubble economy came to an end in the early 1990s business would turn bad for them, and they would be called upon to respond to a changing environment.

\section{CONCLUSION}

We have studied, on the level of business form and the level of individual enterprise, always focusing on innovativeness, the processes of birth, growth, maturity, and stagnation of department stores in Japan. During their 90 years of operations in the twentieth century, they were the only large-scale retail form of business for the first 70 of those years, and a principal form of business coexisting with general supermarkets for the last 20 of those years. What enabled them to become firmly entrenched and to grow before the war was an innovativeness by which they quickly broke out of their original form and made low-priced sales a reality targeting the new clientele of the masses. Their postwar growth can be said to have been achieved on the foundations of their prewar legacy, without any fundamental innovations. Rocking their existence was the appearance and then

${ }^{40}$ T. Yui, The History of Saison, vol. 2, p. 403. 
growth of a new form of business, the general supermarket. On the level of form of business, department stores became more largescale, more high-quality-goods oriented, more specialized even as they broke out of the mold of their prototype; on the enterprise level, they grew and expanded by increasing the number of stores and taking on a plurality of business forms. This type of flexible adaptability made possible the department store form of business and their continued existence as enterprises, but whether they can adapt in the midst of diversification of competitive forms of business depends on innovation in management structure. 